\title{
Forbs differentially affect soil microbial community composition and functions in unfertilized ryegrass-red clover leys
}

\author{
Wen-Feng Cong*, Jørgen Eriksen \\ Department of Agroecology, Aarhus University, Blichers Allé 20, Tjele, 8830, Denmark
}

\section{A R T I C L E I N F O}

\section{Keywords:}

Caraway

Fertilization

Forage mixtures

Nitrogen mineralization

Plantain

Soil carbon dynamics

\begin{abstract}
A B S T R A C T
Increasing plant diversity in agroecosystems is proposed to enhance multiple ecosystem services. Adding selected forbs such as caraway (Carum carvi L.) and plantain (Plantago lanceolata L.) to productive grass-clover mixtures can further enhance forage yields, root biomass, uptake of mineral nutrients and improve animal performance. Yet, it remains unclear whether and how adding these forbs to grass-clover mixtures can influence soil microbial communities and associated soil carbon $(\mathrm{C})$ and nitrogen $(\mathrm{N})$ cycling. Based on a three-year grassland experiment varying in species diversity and composition with and without fertilizer application, we determined soil microbial community composition and functions related to $\mathrm{C}$ and $\mathrm{N}$ cycling under laboratory incubations. Results showed that inclusion of caraway modified soil microbial community composition by enhancing fungal-to-bacterial phospholipid fatty acids of the ryegrass-red clover mixture. Adding plantain to the ryegrass-red clover mixture increased the relative decomposition rate of the labile $\mathrm{C}$ pool, but not of the recalcitrant $\mathrm{C}$ pool. Yet, $\beta$-glucosidase activity and net $\mathrm{N}$ mineralization were unchanged due to inclusion of either forb. Moreover, fertilization with cattle slurry generally weakened these forb-induced changes in soil microbial properties. These findings demonstrate that adding selected forbs to unfertilized grass-clover leys can modify soil microbial community composition and associated $\mathrm{C}$ and $\mathrm{N}$ cycling, implying a potential for promoting long-term soil $\mathrm{C}$ sequestration through enhanced fungi-to-bacteria ratio, but a limited role in improving soil $\mathrm{N}$ fertility.
\end{abstract}

\section{Introduction}

Perennial grass-clover mixtures characterized by high productivity, increased resource use, efficient weed suppression and improved soil fertility are increasingly practised in intensively managed grasslands (Finn et al., 2013; Isbell et al., 2017). Agronomists have recently identified several competitive perennial forbs, such as chicory $(\mathrm{Ci}$ chorium intybus L.), caraway (Carum carvi L.) and plantain (Plantago lanceolata L.) (Elgersma et al., 2014; Hogh-Jensen et al., 2006; Sanderson et al., 2003). Adding these forbs to the productive grassclover mixtures can further enhance herbage yield and root biomass (Cong et al., 2017), increase uptake of mineral nutrients from deep soil layers (Pirhofer-Walzl et al., 2011) and improve animal performance in terms of meat production and milk quality (Somasiri et al., 2015). Yet, it remains largely unexplored whether including these forbs in grassclover mixtures can influence soil microbial community composition and associated carbon $(\mathrm{C})$ and nitrogen $(\mathrm{N})$ cycling, which is crucial for assessing their potential for soil $\mathrm{C}$ sequestration and soil $\mathrm{N}$ fertility.

Soil microbial communities mediate key ecosystem processes that control nutrient cycling and organic matter (OM) decomposition. One of the ways that plant species diversity and composition influence soil microbial communities and associated soil $\mathrm{C}$ and $\mathrm{N}$ processes is through changes in the total amount of belowground OM input (Bardgett and Wardle, 2010). For example, increasing plant diversity has been found to enhance soil microbial community biomass, microbial respiration, decomposition rate of labile $\mathrm{C}$ pool and net $\mathrm{N}$ mineralization, which is largely ascribed to increased biomass production associated with greater plant diversity (Dijkstra et al., 2005; Lange et al., 2015; Zak et al., 2003). Another way is through changes in the quality of belowground input that is closely related to the characteristics of added plant species (Bardgett and Wardle, 2010). For example, legumes with high root quality (e.g. low root $\mathrm{C} / \mathrm{N}$ or lignin/ $\mathrm{N}$ ratio) are often found to have higher soil microbial biomass, activity of soil enzymes (e.g. $\beta$ glucosidase) and soil $\mathrm{N}$ mineralization rate than non-leguminous forbs and grasses (Dijkstra et al., 2006; Fornara et al., 2009).

Our recent study has shown that inclusion of plantain enhanced annual herbage yield (by 10-14\%) and root biomass (by 20-44\%) of ryegrass (Lolium perenne L.)-red clover (Trifolium pratense L.) mixtures, while inclusion of caraway maintained the similar herbage yield but slightly increased root biomass (by 9-12\%) of ryegrass-red clover

\footnotetext{
* Corresponding author.

E-mail address: wenfeng.cong@agro.au.dk (W.-F. Cong).
} 
mixtures (Cong et al., 2017). Moreover, Jing et al. (2017) showed that caraway herbage had the highest OM digestibility, followed by white clover and red clover, and plantain with the lowest OM digestibility. Collectively, these results suggest that including caraway and plantain in grass-clover mixtures will differentially affect the quantity and quality of belowground OM input, consequently influencing soil microbial community biomass, composition and functions related to soil $\mathrm{C}$ and $\mathrm{N}$ cycling.

Apart from plant species diversity and composition, agricultural management practices have a large impact on soil microbial properties. Bünemann et al. (2006) showed that fertilization with organic amendments such as animal manure can generally enhance soil microbial biomass and activity through either direct addition of $\mathrm{C}$ and $\mathrm{N}$ sources and/or indirect influence on plant residue returns. Several studies found that plant species effect on soil microbial properties significantly differed in soils of different fertility (Bardgett et al., 1999; Innes et al., 2004). Hence, it remains to be elucidated whether the effect of including caraway or plantain in grass-clover mixtures on soil microbial properties will depend on fertilization with animal manure.

In this study, we first explored how inclusion of caraway or plantain influenced soil microbial properties of the ryegrass-red clover reference mixture in both fertilized (applied as cattle slurry) and unfertilized treatments. Then, we examined how these differences, if any, were related to herbage biomass, root biomass and root quality. We hypothesized that (1) adding caraway or plantain to the reference mixture influences soil microbial community biomass and microbial $\mathrm{C}$ and $\mathrm{N}$ cycling through changes in root $\mathrm{C}$ input and quality; and (2) fertilization weakens these forb-induced effects on soil microbial properties.

\section{Materials and methods}

\subsection{Experimental site and treatments}

A three-year grassland experiment was established in spring 2013 in the long-term (since 1987) organic dairy crop rotation at the Foulumgaard Experimental Station, Aarhus University, Denmark (Eriksen et al., 2015). The preceding crop in 2012 was winter rye. The experimental site was situated on a loamy sandy soil, classified as a Typic Hapludult with $6.4 \%$ clay, $8.5 \%$ silt, $44 \%$ fine sand and $39 \%$ coarse sand. The soil had a pH of 5.9 , and contained $2.0 \%$ organic $\mathrm{C}$ and $0.17 \%$ total $\mathrm{N}$. The annual mean temperature and annual precipitation in $2013-2015$ were $7.8,9.5$ and $8.6^{\circ} \mathrm{C}$, and 636,853 and $904 \mathrm{~mm}$, respectively.

The experiment was laid out as a completely randomized block design with species composition and fertilization as the two fixed factors, and with three replicates. The plant species composition consisted of four pure stands (perennial ryegrass, Lolium perenne L.; red clover, Trifolium pratense L.; caraway, Carum carvi L. and plantain, Plantago lanceolata L.), one binary stand (the ryegrass-red clover reference mixture) and two three-species stands (ryegrass-red clover-caraway and ryegrass-red clover-plantain mixtures). Two levels of cattle slurry (0 and $250 \mathrm{~kg}$ total $\mathrm{N} \mathrm{ha}^{-1} \mathrm{yr}^{-1}$ with $52 \% \mathrm{NH}_{4}{ }^{+}-\mathrm{N}$ ) were applied across all stands. In total, we had 42 plots with the plot size of $8 \mathrm{~m}$ length $\times 1.5 \mathrm{~m}$ width. In each plot, 10 rows of seeds $(0.12 \mathrm{~m}$ row distance) were sown by machine in May 2013. Adjacent plots were separated by a $0.3 \mathrm{~m}$ buffer.

The sowing proportions of plant species are 50:50 for the binary mixture and 20:20:60 for the three-species mixtures. Optimum seed rates in pure stands were $15,4,12$ and $12 \mathrm{~kg} \mathrm{ha}^{-1}$ for perennial ryegrass, red clover, caraway and plantain, respectively. The seed rate of each species in a mixture was calculated by multiplying the seed rate of the species in its pure stand with the sowing proportion of the species in the respective mixture. Cattle slurry was applied four times during the growing season in both 2014 and 2015; with $100 \mathrm{~kg} \mathrm{~N} \mathrm{ha}^{-1} \mathrm{yr}^{-1}$ at the beginning of the growing season and $50 \mathrm{~kg} \mathrm{~N}^{-1} \mathrm{yr}^{-1}$ immediately after the first, second and third harvests. All plots received a one-off
$200 \mathrm{~kg} \mathrm{~K} \mathrm{ha}{ }^{-1}\left(\mathrm{~K}_{2} \mathrm{SO}_{4}\right)$ application to avoid potassium and sulphur deficiency. In dry periods of the growing seasons, $50-60 \mathrm{~mm}$ irrigation was applied.

\subsection{Soil sampling and soil chemical properties}

Just prior to the third harvest in mid-August 2015, eight soil cores ( $2 \mathrm{~cm}$ inner diameter) per plot were taken to a depth of $10 \mathrm{~cm}$. Soil cores were taken randomly in three mixed stands. Given that $12-41 \%$ of biomass yields were occupied by weeds across four pure stands, soil cores were thus taken adjacently to the sown plant species in pure stands meanwhile avoiding weed patches to minimize the side effects from weeds. The samples were pooled, transferred to the lab and sieved on a $4 \mathrm{~mm}$-size mesh screen to remove larger roots, animals and stones to obtain homogenized samples. A subsample was ground in a ball mill and determined by Elemental Vario EL C/N Analyzer (Hanau, Germany) to measure total $\mathrm{C}$ and $\mathrm{N}$ content. As expected, soil C, N content or soil $\mathrm{C} / \mathrm{N}$ ratio did not differ between stands after just three years, but fertilization with cattle slurry significantly enhanced soil $\mathrm{C}$ and $\mathrm{N}$ content (Table S1).

\subsection{Soil microbial community biomass and composition}

The phospholipid fatty acids (PLFAs) analysis is a rapid and sensitive method to detect broad shifts in soil microbial community that regulate soil C and N cycling (Bardgett et al., 1999; Frostegård et al., 2011). The principle of the PLFAs method is that it creates a fingerprint of the community structure using lipids of microbial membranes as biomarkers for specific microbial groups (Zelles, 1999). The total concentration of PLFAs can also be used as a measure of viable microbial biomass (Zelles et al., 1997). On the same day of soil sampling, about $2 \mathrm{~g}$ moist soil was subsampled from each of the treatments. The PLFAs were then extracted using the same procedure described by Petersen et al. (2002). In brief, fatty acids were first extracted using a modified single-phase Bligh-Dyer extraction approach. Phospholipids were then isolated by solid phase extraction, followed by alkaline trans-esterification converting ester-linked fatty acids to the corresponding methyl esters. An internal standard (13:0 Me/19:0 Me) was included for quantification of PLFAs. In total, 19 PLFAs ( $>0.3 \%$ ) were identified and subsequently classified into specific microbial groups: gram-positive bacteria, gram-negative bacteria, actinomycete, fungi and nonspecific group (Table 1). Given that many PLFAs are found to be nonspecific and common across taxa (Ruess and Chamberlain, 2010; Frostegård et al., 2011), only widely accepted biomarkers are cautiously selected to represent the corresponding microbial groups in this study.

\subsection{Soil microbial functions related to $C$ and $N$ cycling}

\subsubsection{Laboratory soil respiration}

Microbial respiration was determined using the procedure described

Table 1

List of 19 identified PLFAs with classification into specific microbial groups.

\begin{tabular}{lll}
\hline Group & Name & Reference \\
\hline Bacteria & & \\
Gram-positive & $\begin{array}{l}15: 0, i 15: 0, a 15: 0, i 16: 0, \\
\text { i17:0, a17:0 }\end{array}$ & Frostegård and Bååth, 1996 \\
Gram-negative & $c y 17: 0, c y 19: 0$ & \\
Actinomycete & $10 \mathrm{Me} 16: 0,10 \mathrm{Me} 17: 0$, & Frostegård and Bååth, 1996 \\
& $10 \mathrm{Me} 18: 0$ & \\
Fungi & $18: 2 \omega 6 c$ & Felles, 1999 \\
Non-specific & $14: 0,16: 0,16: 1 \omega 5 c$, & Ruess and Chamberlain, 2010; \\
& $16: 1 \omega 7 c, 18: 0,18: 1 \omega 9 c$, & Frostegård et al., 2011 \\
& $18: 1 \omega 9 t$ & \\
\hline
\end{tabular}


by Cong et al. (2014). In brief, about $30 \mathrm{~g}$ sieved moist soil was incubated in a $250 \mathrm{ml}$ jar closed with a cotton plug at $20^{\circ} \mathrm{C}$ over 112 days. Soil sample was kept at $60 \%$ of water holding capacity by supplying deionized water every week. The production of carbon dioxide $\left(\mathrm{CO}_{2}\right)$ was measured five times: on days 2, 7, 14, 56, 112 after filling the bottles. On each date, two headspace samples in the begininng and after $4 \mathrm{~h}$ (days $2,7,14$ ) or $24 \mathrm{~h}$ (days 56,112 ) incubation were analyzed for $\mathrm{CO}_{2}$ on the Micro GC 3000 Gas Analyzer. Daily soil respiration rate was calculated by determining the difference in $\mathrm{CO}_{2}$ concentrations between the two samples. To assess the decomposition rate of labile and recalcitrant $\mathrm{C}$ pools, daily respiration rate was fitted to a two-pool $\mathrm{C}$ model (Dijkstra et al., 2005).

$R_{t}=C_{l} k e^{-k t}+c$

where $R_{t}$ is the daily C respiration rate $\left(\mathrm{mg} \mathrm{kg}^{-1}\right.$ soil d ${ }^{-1}$ ) at time $t, C_{l}$ and $k$ are the pool size and the relative decomposition rate $\left(\mathrm{d}^{-1}\right)$ for the labile $\mathrm{C}$ pool and $c$ is the absolute decomposition rate $\left(\mathrm{mg} \mathrm{kg}^{-1}\right.$ soil $\mathrm{d}^{-1}$ ) of recalcitrant $C$ pool. All parameters were optimized by minimizing the root-mean-square error (RMSE). The coefficient of determination $\left(\mathrm{R}^{2}\right)$ between predicted and observed respiration rates was on average $0.965(S D=0.029)$, indicating strong reliability of this model.

\subsection{2. $\beta$-glucosidase assay}

$\beta$-glucosidase, as one of the most adundant extracellular enzymes, is involved in the enzymatic degradation of cellulose in soil. $\beta$-glucosidase activity is considered as an important biological indicator of soil fertility (Turner et al., 2002). $\beta$-glucosidase activity was assayed by the method of Eivazi and Tabatabai (1988), using the substrate $\rho$-nitrophenyl- $\beta$-D-glucoside ( $\rho N P G)$. Briefly, about $2 \mathrm{~g}$ sieved soil was mixed with $4 \mathrm{ml}$ of $0.05 \mathrm{M}$ modified universal buffer $(\mathrm{pH}=6)$ and $1 \mathrm{ml}$ $\rho N P G(25 \mathrm{mM})$ in a $10 \mathrm{ml}$ tube, and then incubated in a water bath for $2 \mathrm{~h}$ at $20^{\circ} \mathrm{C}$. The reaction was terminated by adding $1 \mathrm{ml}$ of $\mathrm{CaCl}_{2}$ $(0.5 \mathrm{M})$ and $2 \mathrm{ml}$ of $0.1 \mathrm{M}$ Tris buffer $(\mathrm{pH}=12)$. The mixture was

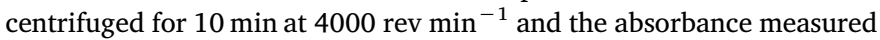
at $400 \mathrm{~nm}$. All measurements were carried out in triplicate for each soil sample and a blank. Values were corrected for a blank. $\beta$-glucosidase activity was expressed as $\mathrm{mg} \rho$-nitrophenol $(\rho \mathrm{NP}) \mathrm{kg}^{-1}$ soil $\mathrm{h}^{-1}$.

\subsubsection{Soil potential net $N$ mineralization}

Two 20-g subsamples of sieved soils were used to measure soil potential net $\mathrm{N}$ mineralization (Cong et al., 2014). In brief, one subsample was extracted immediately with $50 \mathrm{ml}$ of $1 \mathrm{M} \mathrm{KCl}$ for mineral $\mathrm{N}$ analysis. The other subsample was adjusted to $65 \%$ of water holding capacity, covered with polyethylene film and incubated in the dark at $20^{\circ} \mathrm{C}$ for 6 weeks. Soil moisture content was kept constant throughout the incubation period. After incubation, the subsample was extracted again for mineral $\mathrm{N}$ analysis. The $\mathrm{KCl}$ extracts were filtered and analyzed for concentrations of $\mathrm{NH}_{4}{ }^{+}-\mathrm{N}$ and $\mathrm{NO}_{3}{ }^{-}-\mathrm{N}$ using a Technicon Auto-Analyzer III (Bran + Luebbe, Norderstedt, Germany). The soil potential net $\mathrm{N}$ mineralization rate $\left(\mathrm{mg} \mathrm{N} \mathrm{kg}^{-1}\right.$ soil $\left.\mathrm{d}^{-1}\right)$ was calculated by subtracting pre-incubation soil mineral $\mathrm{N}$ from post-incubation soil inorganic $\mathrm{N}$ concentrations and dividing it by the incubation period of 42 days.

\subsection{Herbage yield and root biomass}

The data of herbage yield and root biomass were obtained from a parallel study conducted within the same experiment (Cong et al., 2017). Briefly, the harvests were performed four times in each of two production years (2014 and 2015). At each harvest, herbage dry matter yield was determined by cutting the herbage at $7 \mathrm{~cm}$ stubble height and drying ca. $500 \mathrm{~g}$ subsample at $80^{\circ} \mathrm{C}$. Botanical composition of plant mixtures was measured by separating ca. $300 \mathrm{~g}$ subsample into each of the sown species and pooled unsown species (i.e. weeds). The cumulative herbage biomass yield of each sown species and weeds up to soil sampling time was calculated by summing their respective annual biomass yield in 2014 and biomass yield in the first three harvests in 2015. Notably, despite a higher sowing proportion (i.e. 60\%), caraway and plantain represented only $18-22 \%$ and $38-41 \%$ of the cumulative herbage yield in their respective mixtures (see Fig. S1). Standing root biomass were determined immediately after the 3rd harvest in 2015 using the auger method. Roots were retrieved by washing soil samples on a $425-\mu \mathrm{m}$ mesh and subsequent repeated decantation from a container onto the sieve (Cong et al., 2017).

\subsection{Root quality parameters}

Within each of the four pure stands, three individual plants of sown species were dug out up to $10 \mathrm{~cm}$ to obtain fresh roots. Roots were then washed, dried and ground in a ball mill. Root $\mathrm{C}$ and $\mathrm{N}$ contents were measured using Elemental Vario EL C/N Analyzer (Hanau, Germany). Lignin content of root samples was determined by the acid detergent lignin method (Van Soest, 1967). Root C/N ratio and lignin/N ratio were then calculated to indicate root quality.

\subsection{Statistical analysis}

The linear mixed-effects model was employed to analyze the effects of species composition and fertilization on cumulative herbage yield, soil $\mathrm{C}$ and $\mathrm{N}$ content, and microbial properties, with blocks as random effects and with species composition and fertilization as fixed effects. Differences between treatments were tested using Tukey's post hoc test. The molar percentages (mol\%) of 19 PLFAs were investigated by a principal component analysis (PCA) after $\log (\mathrm{mol} \%+1)$ transformation. Relationships between herbage yield, root biomass, soil $\mathrm{C}$ and $\mathrm{N}$ content, microbial properties, and root quality parameters (i.e. $\mathrm{C} / \mathrm{N}$ ratio and lignin/N ratios) were tested using simple linear regression. All analyses were performed using the $R$ software version 3.4.1.

\section{Results}

\subsection{Species composition and fertilization effects on soil microbial properties}

The effect of plant species composition on soil microbial community biomass (measured as total PLFAs) depended on fertilization at a marginal significance level $(P=0.087$; Table 2$)$ : without fertilization, caraway pure stand hosted the highest microbial biomass among all stands, but this effect disappeared when slurry was applied (Fig. 1A). The similar trend was also observed for bacterial PLFAs (Fig. 1B), grampositive bacterial, gram-negative bacterial, actinomycete and non-specific PLFAs (Fig. S2). Notably, fungal PLFAs in caraway pure stand were significantly larger than the other three pure stands, independent of fertilization. In addition, inclusion of caraway significantly enhanced fungal PLFAs of the ryegrass-red clover reference mixture (Fig. 1C), consequently leading to higher fungal-to-bacterial PLFAs (Fig. 1D). In contrast, neither total PLFAs nor PLFAs from specific microbial group changed when plantain was included in the reference mixture. Fertilization generally enhanced total and subgroup microbial biomass, but did not affect fungal-to-bacterial PLFAs.

Principal component analysis of the PLFA profile showed large differences in soil microbial community composition between stands when no fertilizer was applied (Fig. 2A). Specifically, caraway pure stand ("Cc") was clearly separated from the reference mixture ("Lp-Tp") along the PC1 axis, explaining $42 \%$ of the total variation. The compo-

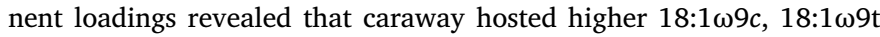
and $18: 2 \omega 6 c$, whereas the reference mixture had higher gram-positive bacteria featured by $i 15: 0, a 15: 0$ and i17:0 (Fig. 2A; Fig. S3). The ryegrass-red clover-caraway mixture containing higher $18: 2 \omega 6 c$ and 10Me18:0 was further separated from the reference mixture along the PC2 axis, explaining $20 \%$ of the variation. Inclusion of plantain ("LpTp-Pl") also shifted soil microbial community composition of the 
Table 2

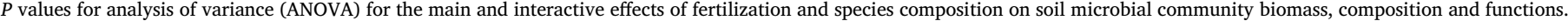

\begin{tabular}{|c|c|c|c|c|}
\hline Soil microbial properties & & Fertilization & Species composition & Fertilization $\times$ Species composition \\
\hline Biomass & Total PLFAs & $<0.001^{* * *}$ & 0.180 & $0.087 \dagger$ \\
\hline \multirow[t]{7}{*}{ Composition } & Bacterial PLFAs & $<0.001^{* * *}$ & 0.710 & $0.089 \dagger$ \\
\hline & Fungal PLFAs & $0.090 \dagger$ & $<0.001^{* * *}$ & 0.940 \\
\hline & Fungal-to-bacterial PLFAs & 0.990 & $0.002^{* *}$ & 0.990 \\
\hline & Gram-positive $\left(\mathrm{G}^{+}\right)$bacterial PLFAs & $0.002^{* *}$ & 0.840 & $0.033^{*}$ \\
\hline & Gram-negative $\left(\mathrm{G}^{-}\right)$bacterial PLFAs & $<0.001^{* * *}$ & 0.200 & 0.760 \\
\hline & Actinomycete PLFAs & $0.039^{*}$ & $0.059 *$ & $0.003^{* *}$ \\
\hline & Non-specific PLFAs & $0.002^{* *}$ & 0.24 & 0.230 \\
\hline \multirow{6}{*}{$\begin{array}{l}\text { Functions } \\
\qquad(\mathrm{C} \text { and } \mathrm{N} \text { cycling })\end{array}$} & Decomposition rate of labile C pool $(k)$ & $<0.001^{* * *}$ & $0.068 \dagger$ & $0.078 \dagger$ \\
\hline & Decomposition rate of recalcitrant $\mathrm{C}$ pool $(c)$ & $<0.001^{* * *}$ & 0.370 & 0.360 \\
\hline & $\beta$-glucosidase activity & $<0.001^{* * *}$ & $0.037^{*}$ & 0.710 \\
\hline & Net $\mathrm{N}$ mineralization rate & $<0.001^{* * *}$ & $0.003^{* *}$ & 0.300 \\
\hline & Net ammonification rate & 0.290 & $<0.001^{* * *}$ & 0.950 \\
\hline & Net nitrification rate & $<0.001^{* * *}$ & $0.066 \dagger$ & $0.017^{*}$ \\
\hline
\end{tabular}

${ }^{* * * P}<0.001 ; * * P<0.01 ; * P<0.05 ; \dagger P<0.1$.

reference mixture along PC2, mainly by increasing the perecentage of non-specific PLFAs, such as 14:0, 16:0 (Fig. S3). In contrast, fertilization generally weakened the differences in soil microbial community composition between stands, evidenced by a tendency of convergence towards origin (Fig. 2B).

The effect of species composition on the relative decomposition rate of the labile C pool $(k)$ also depended on fertilization $(P=0.078$ at a marginal significance level; Table 2). Without fertilization, $k$ was higher in pure stands of red clover and caraway than those of ryegrass and plantain (Fig. 3A). Adding plantain to the reference mixture led to a significantly higher $k$. The absolute decomposition rate $(c)$ of the recalcitrant $\mathrm{C}$ pool was significantly enhanced by fertilization, but did not differ between all stands (Fig. 3B).
Regardless of fertilization, $\beta$-glucosidase activity significantly differed between stands ( $P=0.037$; Table 2$)$, with pure stand of caraway being significantly higher than ryegrass pure stand and all the mixtures (Fig. 3C). Inclusion of either caraway or plantain did not significantly affect $\beta$-glucosidase activity in soils of the reference mixture. A similar trend was observed for net $\mathrm{N}$ mineralization rate, except that pure stand of red clover had significantly higher $\mathrm{N}$ mineralization rate than that of ryegrass (Fig. 3D). The differences in net $\mathrm{N}$ mineralization rate were largely attributed to those in net ammonification rate rather than net nitrification rate (Fig. S4). Fertilization significantly enhanced net $\mathrm{N}$ mineralization rate by $21 \%(P<0.001$; Table 2$)$, with net nitrification rate accounting for the most increase.
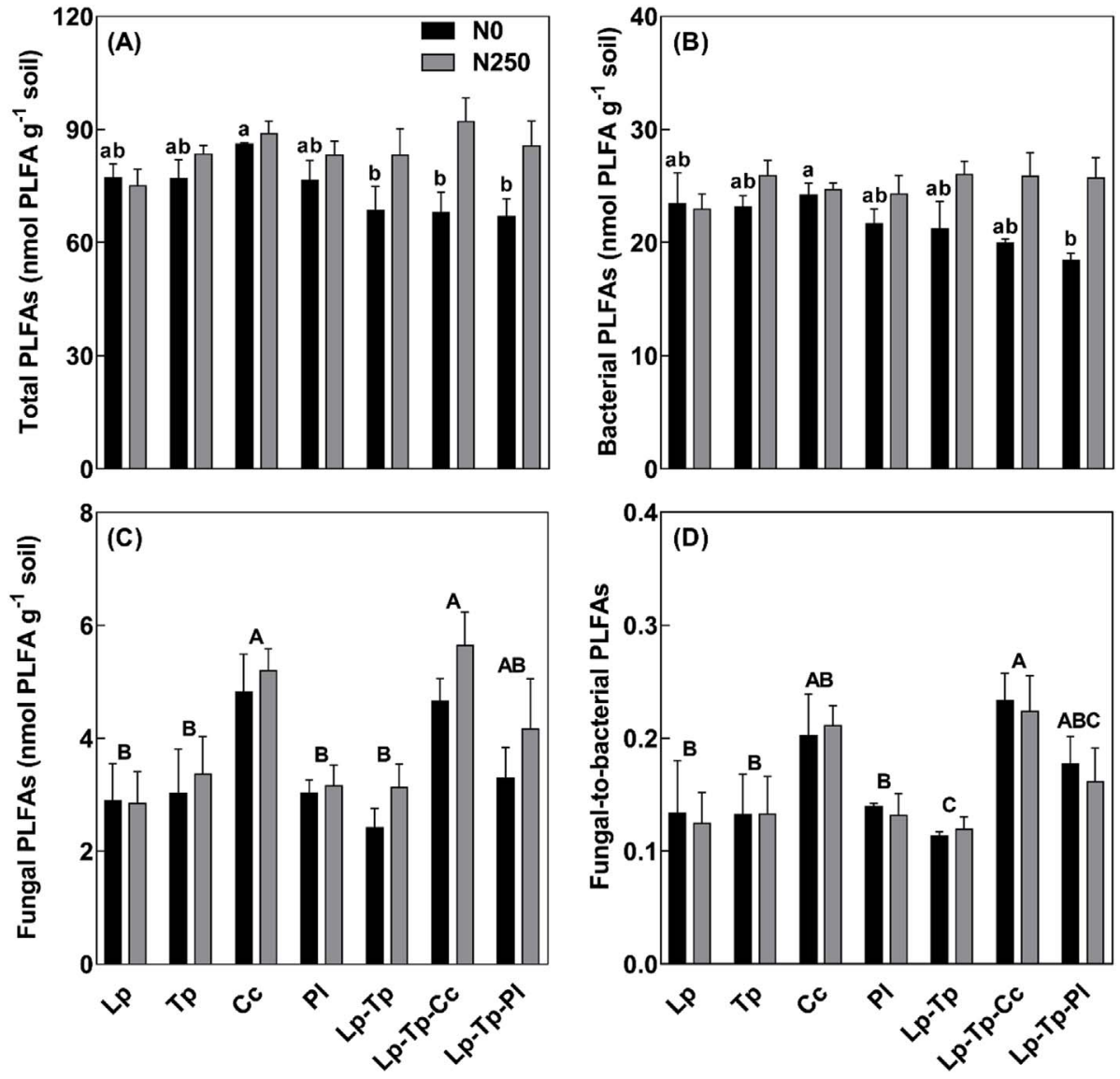

Fig. 1. Soil microbial community biomass ( $A$, total PLFAs) and composition ( $B$, bacterial PLFAs; $C$, fungal PLFAs; $D$, fungal-to-bacterial PLFAs) in soils from four pure and three mixed stands. Data are means $\pm \mathrm{SE}(n=3)$. Means with different capital letters show significant differences $(P<0.05)$ between stands across two fertilization levels. Means with different lowercase letters show significant differences $(P<0.05)$ between stands under no fertilization (i.e. N0 in Panels A and B). Lp, Tp, Cc or Pl refer to the pure stand of ryegrass, red clover, caraway or plantain, respectively. Lp-Tp, Lp-Tp-Cc or Lp-Tp-Pl represents the ryegrass-red clover reference mixture, the reference mixture with inclusion of caraway or plantain, respectively. 

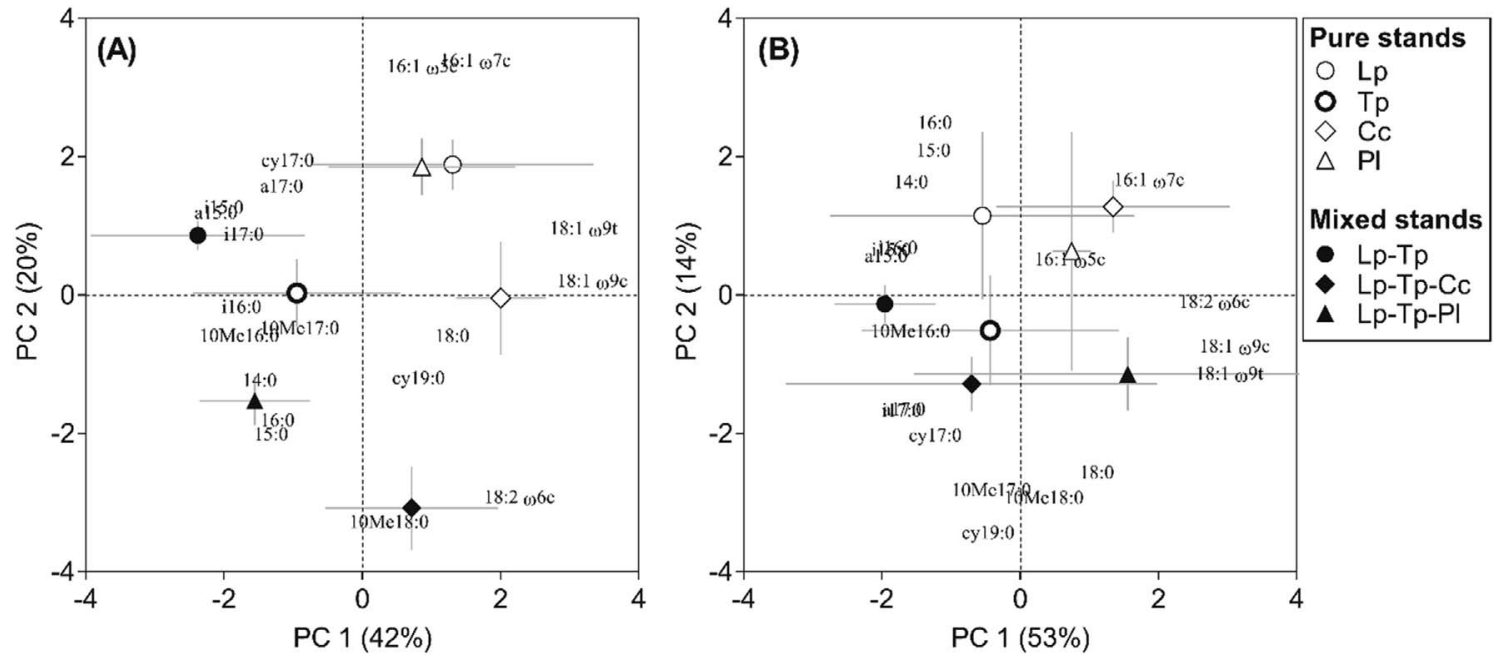

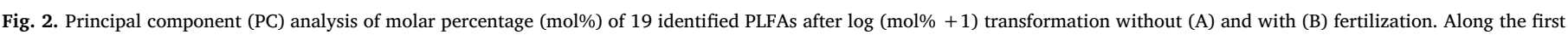

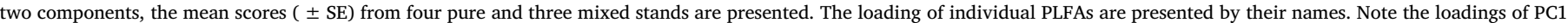
and PC2 were both multipled by eight for clearer presentation. Abbreviations can be referred to Fig. 1.

\subsection{Correlations between soil properties, herbage yield, root biomass and} root quality parameters

Cumulative herbage yield significantly differed between stands $(P<0.001$, Fig. S1). Inclusion of plantain significantly enhanced herbage yield of the reference mixture, while the same pattern was also observed for root biomass (see Fig. 4 in Cong et al., 2017). Surprisingly, neither herbage yield nor root biomass significantly correlated with any of soil chemical or microbial variables, except for a positive correlation between herbage yield and $k$ (Table 3 ). In contrast, soil C content positively correlated with soil microbial biomass (total PLFAs) and microbial functions related to $\mathrm{C}$ cycling, such as $k, c$, and $\beta$-glucosidase activity (Table 3 ).

Total PLFAs and bacterial PLFAs positively correlated with microbial $\mathrm{C}$ cycling (i.e. $k, c$ and $\beta$-glucosidase activity). Interestingly, fungal PLFAs positively related to $k$ rather than $c$, suggesting that the fungal PLFAs mainly mediated $\mathrm{C}$ cycling of labile $\mathrm{C}$ pool. As expected, there were good correlations between microbial $\mathrm{C}$ cycling and microbial $\mathrm{N}$
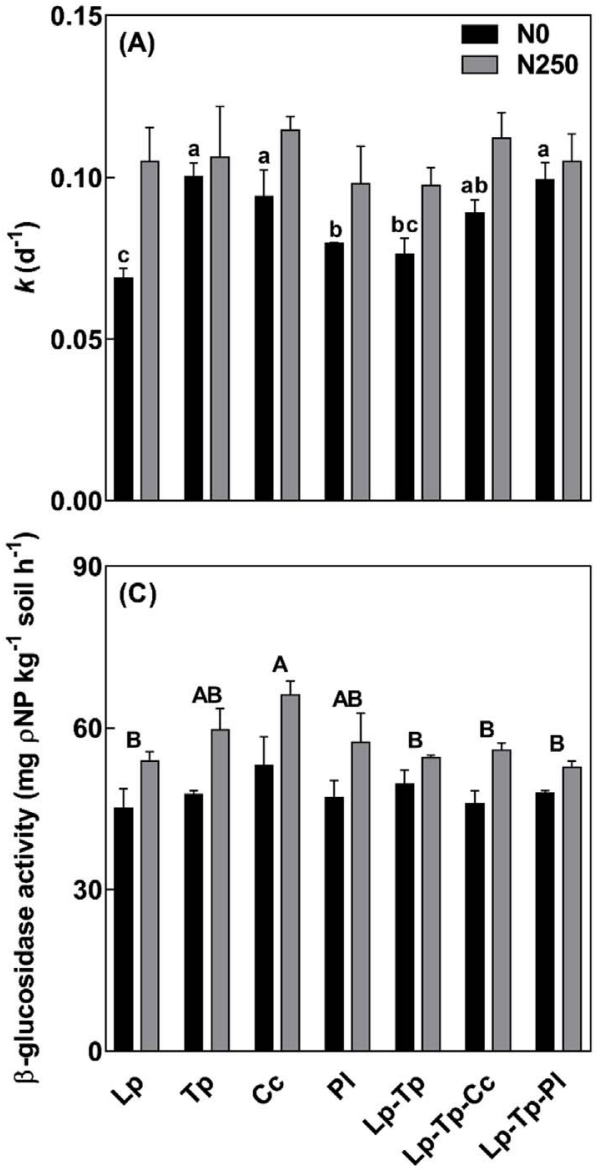
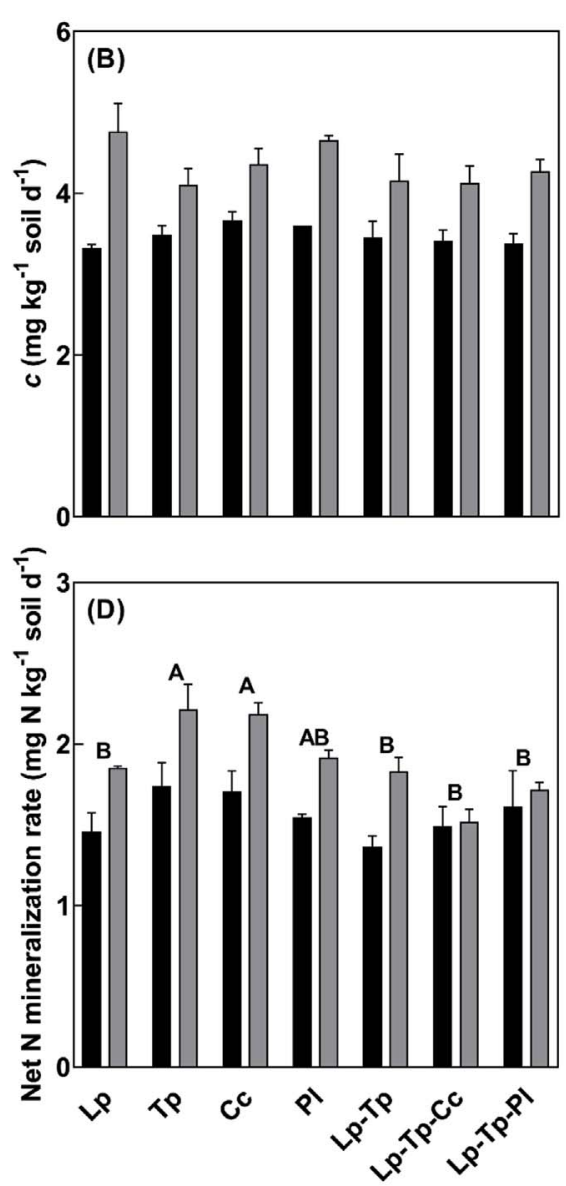

Fig. 3. Soil microbial functions related to $C$ cycling ( $A$, the relative decomposition rate $k$ of the labile $C$ pool; $B$, the absolute decomposition rate $c$ of the recalcitrant $C$ pool; $C$, $\beta$-glucosidase activity) and $\mathrm{N}$ cycling ( $D$, net $\mathrm{N}$ mineralization rate) in soils from four pure and three mixed stands. Data are means \pm SE $(n=3)$. Means with different capital letters show significant differences $(P<0.05)$ between stands across two fertilization levels. Means with different lowercase letters show significant differences $(P<0.05)$ between stands under no fertilization (i.e. N0, in Panel A). Abbreviations can be referred to Fig. 1. 

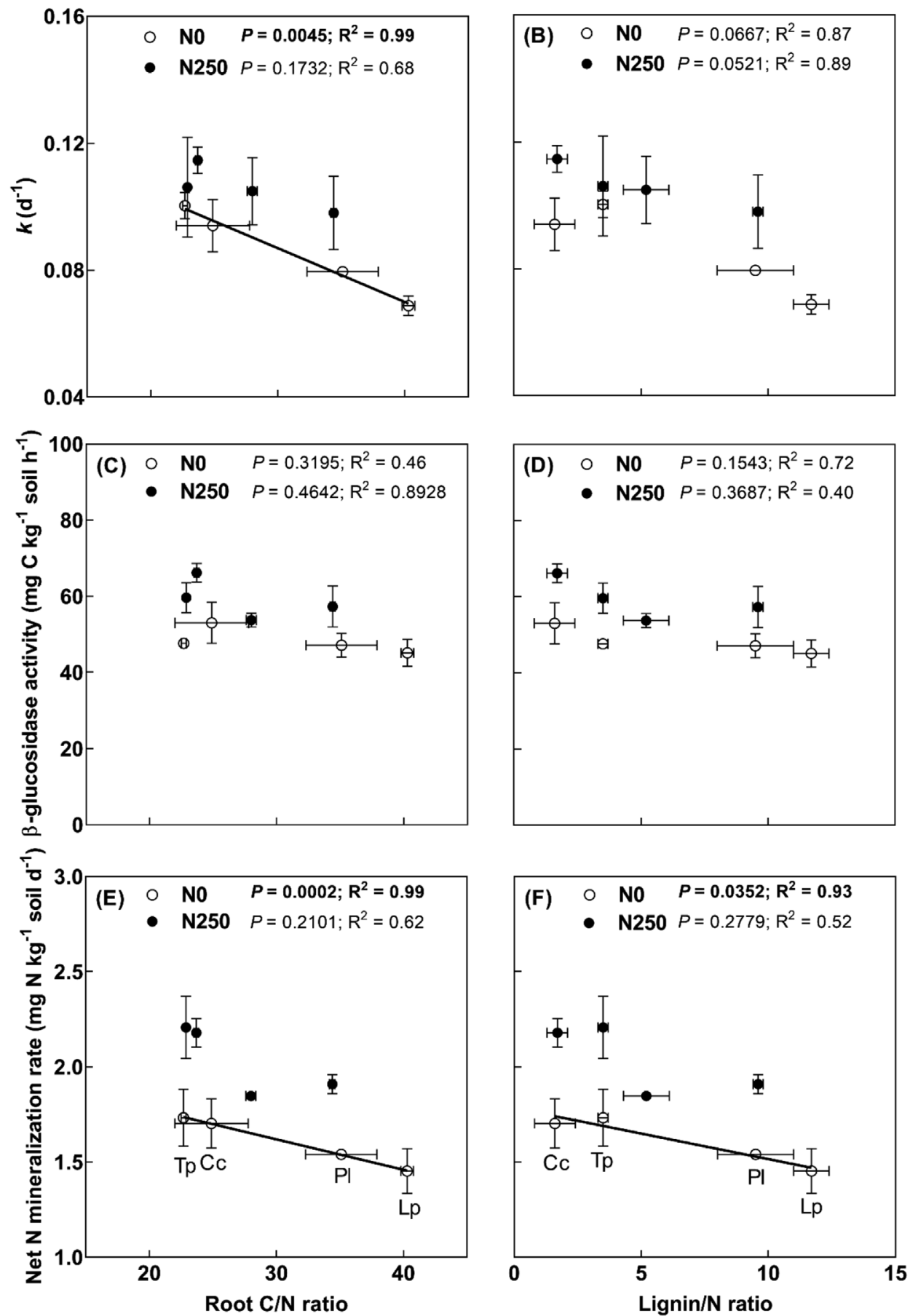

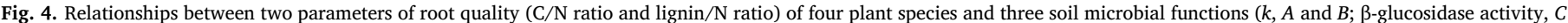

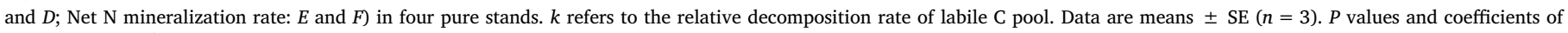

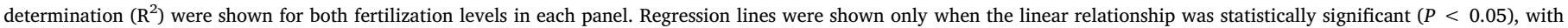
each point labeled with corresponding plant species. Abbreviations can be referred to Fig. 1 .

cycling (i.e. net $\mathrm{N}$ mineralization).

Root quality parameters significantly differed between plant species (Table 4). Overall, red clover and caraway had higher root $\mathrm{N}$ content, lower root $\mathrm{C} / \mathrm{N}$ ratio, lower lignin content, and lower lignin/ $\mathrm{N}$ content than ryegrass and plantain. Fertilization hardly influenced root quality parameters of red clover, caraway and plantain, but significantly enhanced root $\mathrm{N}$ content and reduced root lignin content of ryegrass. As expected, we found (marginally) significant negative correlations between root quality parameters (root $\mathrm{C} / \mathrm{N}$ and lignin/ $\mathrm{N}$ ratios) and microbial $\mathrm{C}$ and $\mathrm{N}$ cycling (i.e. $k$ and net $\mathrm{N}$ mineralization) (Fig. 4).

\section{Discussion}

We demonstrated that adding forb species (caraway or plantain) to grass-clover mixtures influenced soil microbial community composition and associated $\mathrm{C}$ and $\mathrm{N}$ cycling. But these effects differed between the two forbs. Specifically, inclusion of caraway in the ryegrass-red clover reference mixture significantly increased fungal PLFA $(18: 2 \omega 6 c)$ but decreased certain gram-positive bacterial PLFAs (i15:0, a15:0 and i17:0), thereby enhancing fungal-to-bacterial PLFAs (Figs. 1 and 2). Fungi have higher $\mathrm{C}$ utilization efficiency and lower ecosystem $\mathrm{N}$ losses (e.g. leaching) than bacteria (de Vries and Bardgett, 2012; Six et al., 
Table 3

Pearson's correlation coefficients $(r)$ among herbage yield, root biomass, soil chemical properties and soil microbial community biomass, composition and functions.

\begin{tabular}{|c|c|c|c|c|c|c|c|c|c|c|c|c|c|}
\hline${ }^{\S}$ Parameters & $\begin{array}{l}\text { Herbage } \\
\text { yield }\end{array}$ & $\begin{array}{l}\text { Root } \\
\text { biomass }\end{array}$ & Soil C & Soil N & Soil C/N & $\begin{array}{l}\text { Total } \\
\text { PLFAs }\end{array}$ & $\begin{array}{l}\text { Bacterial } \\
\text { PLFAs }\end{array}$ & $\begin{array}{l}\text { Fungal } \\
\text { PLFAs }\end{array}$ & $\begin{array}{l}\text { Fungal/ } \\
\text { Bacterial }\end{array}$ & $k$ & $c$ & $\beta$-glucosidase & Net $\mathrm{N}$ min \\
\hline Herbage yield & & $0.65^{* * *}$ & 0.11 & 0.07 & 0.04 & -0.01 & 0.04 & -0.13 & -0.16 & $0.33^{*}$ & 0.27 & 0.13 & 0.13 \\
\hline Root biomass & & & 0.14 & 0.08 & 0.14 & -0.02 & -0.04 & 0.11 & 0.17 & 0.22 & 0.06 & -0.04 & -0.17 \\
\hline Soil C & & & & $0.75^{* * *}$ & 0.07 & $0.45^{* *}$ & 0.25 & 0.14 & -0.06 & $0.33^{*}$ & $0.67 * * *$ & $0.54^{* * *}$ & $0.29 \dagger$ \\
\hline Soil N & & & & & $-0.32 *$ & $0.39^{*}$ & 0.16 & 0.05 & -0.10 & $0.28 \dagger$ & $0.51^{* * *}$ & $0.48^{* *}$ & 0.09 \\
\hline Soil C/N & & & & & & -0.08 & 0.12 & 0.00 & -0.04 & -0.01 & 0.08 & -0.04 & -0.10 \\
\hline Total PLFAs & & & & & & & $0.46^{* *}$ & $0.30 \dagger$ & 0.09 & 0.10 & $0.34^{*}$ & $0.52^{* * *}$ & 0.18 \\
\hline Bacterial PLFAs & & & & & & & & 0.23 & -0.08 & $0.32 *$ & $0.47 * *$ & $0.47^{* *}$ & 0.22 \\
\hline Fungal PLFAs & & & & & & & & & $0.92^{* * *}$ & $0.40 *$ & $* 0.25$ & $0.32^{*}$ & 0.10 \\
\hline Fungal/Bacterial & & & & & & & & & & $0.26 \dagger$ & 0.02 & 0.11 & 0.04 \\
\hline$k$ & & & & & & & & & & & $0.49^{* * *}$ & $0.42^{* *}$ & $0.39^{*}$ \\
\hline$c$ & & & & & & & & & & & & $0.63^{* * *}$ & $0.48^{* *}$ \\
\hline$\beta$-glucosidase & & & & & & & & & & & & & $0.39^{*}$ \\
\hline
\end{tabular}

Net $\mathrm{N}$ min.

$\S k$, decomposition rate of labile $\mathrm{C}$ pool; $c$, decomposition rate of recalcitrant $\mathrm{C}$ pool; Net $\mathrm{N}$ min, net soil $\mathrm{N}$ mineralization rate.

Asterisks indicate the significance test of the correlations: ${ }^{* * *} P<0.001 ; * * P<0.01 ; * P<0.05 ; \dagger P<0.1$.

Table 4

Root quality parameters of the four sown plant species. The standard errors for the means were shown in brackets.

\begin{tabular}{lllll}
\hline \multirow{2}{*}{ Plant species } & \multicolumn{2}{l}{ Root C/N ratio } & \multicolumn{2}{l}{ Root lignin/N ratio } \\
\cline { 2 - 5 } & N0 & N250 & N0 & N250 \\
\hline Ryegrass & $40.3(0.5)^{\mathrm{a}}$ & $28.0(0.4)^{\mathrm{b}}$ & $11.7(0.7)^{\mathrm{a}}$ & $5.2(0.9)^{\mathrm{b}}$ \\
Red clover & $22.7(0.2)^{\mathrm{b}}$ & $22.9(0.1)^{\mathrm{c}}$ & $3.5(0.2)^{\mathrm{b}}$ & $3.5(0.2)^{\mathrm{c}}$ \\
Caraway & $24.9(2.9)^{\mathrm{b}}$ & $23.7(0.2)^{\mathrm{c}}$ & $1.6(0.8)^{\mathrm{b}}$ & $1.7(0.4)^{\mathrm{d}}$ \\
Plantain & $35.1(2.8)^{\mathrm{a}}$ & $34.4(0.2)^{\mathrm{a}}$ & $9.5(1.5)^{\mathrm{a}}$ & $9.6(0.2)^{\mathrm{a}}$ \\
\hline
\end{tabular}

Means with different lowercase letters showed significant differences $(P<0.05)$ between species within each column under two levels of fertilization.

2006). Hence, higher fungi:bacteria ratio and enhanced root biomass in ryegrass-red clover-caraway mixtures (Cong et al., 2017) jointly suggest that maintaining at least a modest biomass fraction of caraway $(18-22 \%$ in this study) in grass-clover leys can potentially enhance agricultural sustainability in terms of increasing $\mathrm{C}$ sequestration and reducing $\mathrm{N}$ losses in soil. In contrast, adding plantain to the reference mixture did not significantly shift fungal PLFAs or fungi:bacteria ratio (Fig. 1), although it increased the abundance of certain non-specific PLFAs (Fig. 2). Importantly, inclusion of plantain in the reference mixture accelerated the relative decomposition rate ( $k$ ) of labile $C$ pool (Fig. 3), which could partly conteract the benefit of plantain in enhancing longterm soil C sequestration through enhanced root biomass (Cong et al., 2017).

\subsection{Mechanisms underlying enhanced fungi:bacteria ratio by adding caraway}

Plant species can considerably modify soil microbial community composition through changes in the quantity, variety and quality of plant-derived organic substrates (Bardgett et al., 1999; Grayston et al., 1998; Hartmann et al., 2009). Several studies have shown an enhanced fungi:bacteria ratio upon the addition of labile $\mathrm{C}$ sources and suggested that increased abundance of fungi belong to a fast-growing fungal group that specializes in metabolizing relatively large amounts of labile C-rich substrates (Broeckling et al., 2008; Chigineva et al., 2009; de Graaff et al., 2010). Denef et al. (2009) further revealed that the fastgrowing fungi were very active in processing plant-derived labile $\mathrm{C}$ sources since the greatest ${ }^{13} \mathrm{C}$ enrichment was observed in fungal biomarker PLFAs. Our study showed that caraway had high root quality evidenced by low $\mathrm{C} / \mathrm{N}$ ratio and lignin/ $\mathrm{N}$ ratio (Table 4 ), and that low $\mathrm{C} / \mathrm{N}$ ratio was positively related to the relative decomposition rate $(k)$ of labile C pool (Fig. 4). Moveover, fungal PLFAs were found to positively correlate with $k$ rather than $c$, the decomposition rate of recalcitrant $\mathrm{C}$ pool (Table 3 ). These results suggest that caraway enhanced fungal PLFAs and fungi:bacteria ratio of the reference mixture probably through feeding fungi with labile $\mathrm{C}$ sources derived from caraway roots. Further work requires direct demonstration of the utilization of plant-derived labile C sources by fungi using stable isotope probing of PLFAs (Treonis et al., 2004) as well as detailed investigation of fungal community composition using molecular techniques such as high-throughput 18S rDNA and ITS gene pyrosequencing (Anderson and Cairney, 2004).

\subsection{Mechanisms underlying enhanced $C$ cycling of the labile $C$ pool by adding plantain}

Substrate quality is a key factor in influencing decomposition rate of organic matter (Swift et al., 1979). We observed the lowest decomposition rate in ryegrass pure stand, which was probably attributed to low root quality of ryegrass (Table 4). In addition, adding plantain substantially reduced ryegrass biomass of grass-clover mixture (Fig. S1), which thus would increase overall quality of belowground C input. Consequently, this may lead to increased decomposition rate of labile $\mathrm{C}$ pool in plantain-containing mixtures. This is in agreement with the biomass ratio hypothesis (Grime, 1998), which proposes that ecosystem processes in a plant community are determined by the functional traits of plant species and its abundance.

Another possible mechanism could be due to the synergistic effect occurring during decomposition of litter mixtures (Hättenschwiler et al., 2005). For example, Vachon and Oelbermann (2011) showed enhanced decomposition rate of $\mathrm{N}$-poor residue of maize when mixed with $\mathrm{N}$-rich residue of soybean because $\mathrm{N}$ mineralized from soybean can be transferred to maize to facilitate decomposition. This ' $\mathrm{N}$ transfer' mechanism may also work between $\mathrm{N}$-rich red clover and $\mathrm{N}$-poor plantain, which requires further examination.

\subsection{Fertilization and soil fertility mediated the forb-induced changes in soil microbial properties}

We found that fertilization generally enhanced microbial biomass and $\mathrm{C}$ and $\mathrm{N}$ cycling. As expected, fertilization weakened the forb-induced effects on soil microbial properties. However, in contrast with previous findings from several grassland biodiversity experiments (Dijkstra et al., 2005; Lange et al., 2015; Zak et al., 2003), we found that enhanced herbage yield and root biomass in plantain-containing mixtures compared to grass-clover mixtures did not lead to a concurrent increase in soil microbial biomass, $\beta$-glucosidase activity or soil $\mathrm{N} \mathrm{mi-}$ neralization rate. This could be explained by higher soil fertility $(2 \%$ soil organic C) in this study, which may have masked the forb-induced 
effects on soil microbial properties. Indeed, our results showed that soil $\mathrm{C}$ and $\mathrm{N}$ content, rather than herbage yield and root biomass, positively correlated with soil microbial biomass and associated $\mathrm{C}$ and $\mathrm{N}$ cycling (Table 3).

In conclusion, our study provides the first evidence that inclusion of certain forb species such as caraway and plantain differentially influenced soil microbial properties of unfertilized ryegrass-red clover leys, and the differences were probably driven by the quality of soil $\mathrm{C}$ input rather than its quantity. These findings suggest that including caraway and plantain into grass-clover mixtures holds potential for enhancing long-term soil $\mathrm{C}$ sequestration and ecosystem $\mathrm{N}$ retention, but has a limited role in improving soil $\mathrm{N}$ fertility, especially in relatively fertile soils. Yet, these results were obtained based on just one sowing proportion (i.e. $60 \%$ ) of forbs sown with grass-clover leys. Future studies are needed to investigate the range of forb proportions, over which these forb-induced effects on soil microbial properties are evident, and to quantitively understand their potential roles in the build-up of soil C stocks and soil fertility in agricultural grasslands.

\section{Acknowledgements}

The research was supported financially by the Green Development and Demonstration Program 'MultiPlant' project [grant number 3400913-0678] and coordinated by the International Centre for Research in Organic Food Systems (ICROFS). We gratefully acknowledge Karen Søegaard and the staff at Foulumgaard Experimental Station for initiating and running this experiment. We also thank Jingying Jing, Bodil Stensgaard, Olga Alfastsen, Lars Elsgaard and Søren O. Petersen for technical assistance and suggestions in field sampling and laboratory analysis.

\section{Appendix A. Supplementary data}

Supplementary data related to this article can be found at http://dx. doi.org/10.1016/j.soilbio.2018.03.008.

\section{References}

Anderson, I.C., Cairney, J.W.G., 2004. Diversity and ecology of soil fungal communities: increased understanding through the application of molecular techniques. Environmental Microbiology 6, 769-779.

Bardgett, R.D., Mawdsley, J.L., Edwards, S., Hobbs, P.J., Rodwell, J.S., Davies, W.J., 1999 Plant species and nitrogen effects on soil biological properties of temperate upland grasslands. Functional Ecology 13, 650-660.

Bardgett, R.D., Wardle, D.A., 2010. Aboveground-belowground Linkages: Biotic Interactions, Ecosystem Processes, and Global Change. Oxford University Press, New York.

Broeckling, C.D., Broz, A.K., Bergelson, J., Manter, D.K., Vivanco, J.M., 2008. Root exudates regulate soil fungal community composition and diversity. Applied and Environmental Microbiology 74, 738-744.

Bünemann, E.K., Schwenke, G.D., Van Zwieten, L., 2006. Impact of agricultural inputs on soil organisms - a review. Soil Research 44, 379-406.

Chigineva, N.I., Aleksandrova, A.V., Tiunov, A.V., 2009. The addition of labile carbon alters litter fungal communities and decreases litter decomposition rates. Applied Soil Ecology 42, 264-270.

Cong, W.-F., Jing, J., Rasmussen, J., Søegaard, K., Eriksen, J., 2017. Forbs enhance productivity of unfertilised grass-clover leys and support low-carbon bioenergy. Scientific Reports 7, 1422.

Cong, W.-F., van Ruijven, J., Mommer, L., De Deyn, G.B., Berendse, F., Hoffland, E., 2014. Plant species richness promotes soil carbon and nitrogen stocks in grasslands without legumes. Journal of Ecology 102, 1163-1170.

de Graaff, M.-A., Classen, A.T., Castro, H.F., Schadt, C.W., 2010. Labile soil carbon inputs mediate the soil microbial community composition and plant residue decomposition rates. New Phytologist 188, 1055-1064.

de Vries, F.T., Bardgett, R.D., 2012. Plant-microbial linkages and ecosystem nitrogen retention: lessons for sustainable agriculture. Frontiers in Ecology and the Environment 10, 425-432.

Denef, K., Roobroeck, D., Wadu, M., Lootens, P., Boeckx, P., 2009. Microbial community composition and rhizodeposit-carbon assimilation in differently managed temperate grassland soils. Soil Biology and Biochemistry 41, 144-153.

Dijkstra, F.A., Hobbie, S.E., Reich, P.B., 2006. Soil processes affected by sixteen grassland species grown under different environmental conditions. Soil Science Society of America Journal 70, 770-777.

Dijkstra, F.A., Hobbie, S.E., Reich, P.B., Knops, J.M.H., 2005. Divergent effects of elevated $\mathrm{CO}_{2}$, $\mathrm{N}$ fertilization, and plant diversity on soil $\mathrm{C}$ and $\mathrm{N}$ dynamics in a grassland field experiment. Plant and Soil 272, 41-52.

Eivazi, F., Tabatabai, M.A., 1988. Glucosidases and galactosidases in soils. Soil Biology and Biochemistry 20, 601-606.

Elgersma, A., Søegaard, K., Jensen, S.K., 2014. Herbage dry-matter production and forage quality of three legumes and four non-leguminous forbs grown in single-species stands. Grass and Forage Science 69, 705-716.

Eriksen, J., Askegaard, M., Rasmussen, J., Søegaard, K., 2015. Nitrate leaching and residual effect in dairy crop rotations with grass-clover leys as influenced by sward age, grazing, cutting and fertilizer regimes. Agriculture. Ecosystems \& Environment 212, 75-84.

Federle, T., 1986. Microbial distribution in soil—new techniques. In: Megusar, F., Gantar, M. (Eds.), Perspectives in Microbial Ecology, Slovene Society for Microbiology, Ljubljan, pp. 493-498.

Finn, J.A., Kirwan, L., Connolly, J., Sebastia, M.T., Helgadottir, A., Baadshaug, O.H., Belanger, G., Black, A., Brophy, C., Collins, R.P., Cop, J., Dalmannsdottir, S., Delgado, I., Elgersma, A., Fothergill, M., Frankow-Lindberg, B.E., Ghesquiere, A., Golinska, B., Golinski, P., Grieu, P., Gustavsson, A.M., Hoglind, M., Huguenin-Elie, O., Jorgensen, M., Kadziuliene, Z., Kurki, P., Llurba, R., Lunnan, T., Porqueddu, C., Suter, M., Thumm, U., Luscher, A., 2013. Ecosystem function enhanced by combining four functional types of plant species in intensively managed grassland mixtures: a 3-year continental-scale field experiment. Journal of Applied Ecology 50, 365-375.

Fornara, D.A., Tilman, D., Hobbie, S.E., 2009. Linkages between plant functional composition, fine root processes and potential soil $\mathrm{N}$ mineralization rates. Journal of Ecology 97, 48-56.

Frostegård, A., Bååth, E., 1996. The use of phospholipid fatty acid analysis to estimate bacterial and fungal biomass in soil. Biology and Fertility of Soils 22, 59-65.

Frostegård, A., Tunlid, A., Bååth, E., 2011. Use and misuse of PLFA measurements in soils. Soil Biology and Biochemistry 43, 1621-1625.

Grayston, S.J., Wang, S., Campbell, C.D., Edwards, A.C., 1998. Selective influence of plant species on microbial diversity in the rhizosphere. Soil Biology and Biochemistry 30, $369-378$.

Grime, J.P., 1998. Benefits of plant diversity to ecosystems: immediate, filter and founder effects. Journal of Ecology 86, 902-910.

Hartmann, A., Schmid, M., van Tuinen, D., Berg, G., 2009. Plant-driven selection of microbes. Plant and Soil 321, 235-257.

Hättenschwiler, S., Tiunov, A.V., Scheu, S., 2005. Biodiversity and litter decomposition in terrestrial ecosystems. Annual Review of Ecology, Evolution, and Systematics 36, 191-218.

Hogh-Jensen, H., Nielsen, B., Thamsborg, S.M., 2006. Productivity and quality, competition and facilitation of chicory in ryegrass/legume-based pastures under various nitrogen supply levels. European Journal of Agronomy 24, 247-256.

Innes, L., Hobbs, P.J., Bardgett, R.D., 2004. The impacts of individual plant species on rhizosphere microbial communities in soils of different fertility. Biology and Fertility of Soils 40, $7-13$.

Isbell, F., Adler, P.R., Eisenhauer, N., Fornara, D., Kimmel, K., Kremen, C., Letourneau, D.K., Liebman, M., Polley, H.W., Quijas, S., Scherer-Lorenzen, M., 2017. Benefits of increasing plant diversity in sustainable agroecosystems. Journal of Ecology 105, 871-879.

Jing, J., Søegaard, K., Cong, W.-F., Eriksen, J., 2017. Species diversity effects on productivity, persistence and quality of multispecies swards in a four-year experiment. PLoS One 12 e0169208.

Lange, M., Eisenhauer, N., Sierra, C.A., Bessler, H., Engels, C., Griffiths, R.I., Mellado-Vázquez, P.G., Malik, A.A., Roy, J., Scheu, S., Steinbeiss, S., Thomson, B.C., Trumbore, S.E., Gleixner, G., 2015. Plant diversity increases soil microbial activity and soil carbon storage. Nature Communications 6, 6707.

Petersen, S.O., Frohne, P.S., Kennedy, A.C., 2002. Dynamics of a soil microbial community under spring wheat. Soil Science Society of America Journal 66, 826-833.

Pirhofer-Walzl, K., Soegaard, K., Hogh-Jensen, H., Eriksen, J., Sanderson, M.A., Rasmussen, J., Rasmussen, J., 2011. Forage herbs improve mineral composition of grassland herbage. Grass and Forage Science 66, 415-423.

Ruess, L., Chamberlain, P.M., 2010. The fat that matters: soil food web analysis using fatty acids and their carbon stable isotope signature. Soil Biology and Biochemistry 42, 1898-1910.

Sanderson, M.A., Labreveux, M., Hall, M.H., Elwinger, G.F., 2003. Forage yield and persistence of chicory and English plantain. Crop Science 43, 995-1000.

Six, J., Frey, S.D., Thiet, R.K., Batten, K.M., 2006. Bacterial and fungal contributions to carbon sequestration in agroecosystems. Soil Science Society of America Journal 70, 555-569.

Somasiri, S.C., Kenyon, P.R., Kemp, P.D., Morel, P.C.H., Morris, S.T., 2015. Mixtures of clovers with plantain and chicory improve lamb production performance compared to a ryegrasswhite clover sward in the late spring and early summer period. Grass and Forage Science $71,270-280$.

Swift, M.J., Heal, O.W., Anderson, J.M., 1979. Decomposition in Terrestrial Ecosystems. Blackwell, Oxford.

Treonis, A.M., Ostle, N.J., Stott, A.W., Primrose, R., Grayston, S.J., Ineson, P., 2004. Identification of groups of metabolically-active rhizosphere microorganisms by stable isotope probing of PLFAs. Soil Biology and Biochemistry 36, 533-537.

Turner, B.L., Hopkins, D.W., Haygarth, P.M., Ostle, N., 2002. $\beta$-Glucosidase activity in pasture soils. Applied Soil Ecology 20, 157-162.

Vachon, K., Oelbermann, M., 2011. Crop residue input and decomposition in a temperate maize-soybean intercrop system. Soil Science 176, 157-163.

Van Soest, P.J., 1967. Use of detergents in the analysis of fibrous feeds. IV. Determination of plant cell wall constituents. Journal of Association of Official Analytical chemists 50, $50-55$.

Zak, D.R., Holmes, W.E., White, D.C., Peacock, A.D., Tilman, D., 2003. Plant diversity, soil microbial communities, and ecosystem function: are there any links? Ecology 84, 2042-2050.

Zelles, L., 1999. Fatty acid patterns of phospholipids and lipopolysaccharides in the characterisation of microbial communities in soil: a review. Biology and Fertility of Soils 29, $111-129$.

Zelles, L., Palojärvi, A., Kandeler, E., von Lützow, M., Winter, K., Bai, Q.Y., 1997. Changes in soil microbial properties and phospholipid fatty acid fractions after chloroform fumigation. Soil Biology and Biochemistry 29, 1325-1336. 